\title{
Deoxyhemoglobin Measurement
}

National Cancer Institute

\section{Source}

National Cancer Institute. Deoxyhemoglobin Measurement. NCI Thesaurus. Code C124343.

The determination of the amount of deoxyhemoglobin present in a sample. 